20. Pro zatverdzhennia Poriadku skladannia, zatverdzhennia ta kontroliu vykonannia finansovoho planu subiekta hospodariuvannia derzhavnoho sektoru ekonomiky [Electronic resource]: Decree of the Ministry of Economic Development and Trade of Ukraine on 02.03.2015 № 205 - Available at: \www/URL http://zakon2.rada.gov.ua/laws/show/z0300-15

21. Vishwanath, T. Towards Transparency in Finance and Governance [Text] / T. Vishwanath, D. Kaufmann // World Bank. 1999. - 30 p. doi:10.2139/ssrn.258978

22. Koriahin, M. V. Bukhhalterskyi oblik u systemi upravlinnia vartistiu pidpryiemstva: teoretyko-metodolohichni kontseptsii [Text]: Monograph / M. V. Koriahin. - Lviv: LKA, 2012. - 389 p.

23. Korporatyvne upravlinnia $\mathrm{v}$ derzhavnykh kompaniiakh: mizhnarodnyi dosvid [Electronic resource] // Ministry of Economic Development and Trade of Ukraine. - Available at: \www/ URL: http://www.me.gov.ua/Documents/Detail?lang=ukUA\&id=d8035fb7-f1f5-4bde-b614-11881ad84c8c\&title=KorporativneUpravlinniaVDerzhavnikh\%20Kompaniiakh-MizhnarodniiDosvid

24. Sinkov, L. S. Role of non-financial reporting in express stability assessment of mining enterprises [Electronic resource] L. S. Sinkov, E. I. Stepuk // Naukovedenie. - 2015. - Vol. 7 , № 3. - Available at: \www/URL: http://naukovedenie.ru/ PDF/14EVN315.pdf

25. A telling performance Surveying narrative reporting in annual reports [Electronic resource]. - Deloitte, 2009. - Available at: \www/URL: http://www.iasplus.com/en/binary/uk/ 0910atellingperformance.pdf

\section{КОНЦЕПЦИЯ ФОРМИРОВАНИЯ ОТЧЕТНОЙ ИНФОРМАЦИИ ДЛЯ ОЦЕНКИ СИСТЕМЫ УПРАВЛЕНИЯ ФИНАНСАМИ ГОСУДАРСТВЕННЫХ ПРЕДПРИЯТИЙ}

Проведен анализ динамики показателей, характеризующих деятельность государственных предприятий Украины. Определены виды отчетности, которую составляют и предоставляют предприятия заинтересованным лицам. Очерчены основные направления усовершенствования форматов отчетности для государственных предприятий. Разработана матрица согласованности показателей финансовых отчетов. Рекомендовано для государственных предприятий составлять отчет по управлению для оценки качества управленческой деятельности.

Ключевые слова: государственные предприятия, финансовая отчетность, нефинансовые показатели, управление государственным предприятием, оценки деятельности.

Chumak Oksana, PhD, Department of Financial Globalization and Public Debt Management, SESI «Academy of Financial Management»,Kyiv, Ukraine, e-mail: chumak_ov@i.ua, ORCID: http:// orcid.org/0000-0001-6387-2840

Filipishyna Liliya, PhD, Associate Professor, Department of Economics and Production, Pervomayska Branch of the Admiral Makarov National University of Shipbuilding, Ukraine,e-mail: ontariofilpi@mail.ru, ORCID: http://orcid.org/0000-0001-9552-1367

\section{Polins'kyy 0., Bielkina I., Churikanova 0 ., Shyrin A., Yakovenko T., Antoniuk 0.}

\title{
IMPLEMENTATION OF COMPLEX PROTECTION AGAINST RISK IN MACHINE-BUILDING ENTERPRISE'S INNOVATIONS
}

Запропоновано комплексну систему захисту від ризиків інноваційної діяльності машинобудівного підприємства, яка включає принципи: нормативності, економічної обгрунтованості, комплексності, швидкого реагування, безперервності, дієвості, адекватності, забезпеченості ресурсами, розвитку, адміністративного управління, координащіі, професіоналізму, розкриття інформації. Передбачається також оцінка головних критерії, а саме: репутації, можливостей, капіталу, умов реалізації інноваційного проекту.

Ключові слова: ризики інноваційної діяльності, комплексна система захисту, ризик-менеджмент, методи фінансування інноваційних проектів.

\section{Introduction}

The complexity and inconsistency of processes that occur in the external and internal environment of modern machine-building enterprises, the variety of threats and risks that accompany the introduction of innovation projects necessitate the construction of an integrated system of protection against risks when introducing innovations.

Comprehensive protection against risks is a combination of legal, organizational and technical measures that increase counteraction to real and potential, internal and external risks and threats to the activities of the enter- prise that can suspend or inhibit the development of the enterprise's innovation activity.

\section{The object of research and its technological audit}

The machine-building enterprise «Dnepr Polymermash» is chosen as the object of complex protection against risks of innovation activity. An economic analysis is carried out, prospects of innovation activity are assessed, and risks in the machine-building industry are monitored.

The conducted technological audit shows the need to reduce the risks of innovation, caused by a shortage of 
investment resources. It is proposed to use the mechanism of venture financing for these purposes at «Dnepr Polymermash».

\section{The aim and objectives of research}

The aim of this article is implementation of an integrated system of protection against risks in the innovation activity of machine-building enterprise. To achieve this aim, the following objectives are set:

1. To analyze the threats to the market economy of Ukraine.

2. To identify the sources of resources of the system of protection against risks at the «Dnepr Polymermash» enterprise.

3. To identify threats of unauthorized disclosure of commercial secrets and leakage of information resources of the enterprise.

4. To analyze the ability of «Dnepr Polymermash» enterprise to attract and return credit funds.

5. To check the conformity of qualification levelof the personnel potential of the enterprise and its material and technical base to the world standards.

6. To analyze the reputation, opportunities, capital, conditions for the implementation of the innovative project at «Dnepr Polymermash» enterprise.

The goals and objectives of an integrated system for protecting against the risks of machine-building enterprise are determined by the adopted strategies, tactical and operational plans.

\section{Research of existing solutions of the problem}

A significant number of scientific articles and textbooks are devoted to the research of problems of the enterprise's innovation activity. In [1] it is indicated that the results of innovation activity are influenced by organizational dynamics and direct competition. The author of [2] believes that the conceptual development of innovative product models goes hand in hand with the textbook changes in the field of scienceorganization. Simultaneous impact of the hierarchical perspective of innovation and the likely risk of taking a new product to production is considered in [3]. [4] is devoted to the risk of supply of material resources and reduction of possible investments due to the reduction of the complexity of the innovation project. In [5] the influence of creative ideas on the product of competitive advantage is investigated as a strategic innovation result. [6] is devoted to the development and use of mathematical models that facilitate the design of innovation projects. Three types of destructive innovations that can have a negative impact on existing enterprises are considered in [7].

In Ukraine, some methods [8,9] used by foreign authors are used, where the emphasis is mainly on the financial mechanism of investment, not taking into account the specifics of Ukrainian reality.

Features of the sectoral modeling of investment projects are also given in [10-12].

Comparative risk analysis at various stages of development and implementation of an innovative project, compiled from a survey of 40 experts representing the engineering industry, shows that projects at the stage of prospecting research are the least risky for implementation and financing at machine-building enterprises. At the same time, the risk of projects aimed at promoting a new product is much higher [13, 14].

During the development and implementation of such projects, the risk increases due to the significant uncertainty of information and the high probability of errors in forecasting the volume of demand, sales opportunities, determining the position of the goods on the market, setting prices, etc.

The development of a mechanism to protect against the risks of innovation projects implies their classification according to the degree of completeness into categories in accordance with the degree of readiness of the product and novelty of the product (Table 1). Obviously, the attractiveness for project developers and investors will be greater for projects that have a high degree of completeness and a low level of risk $[15,16]$.

Table 1

Classification of risks of innovation projects in machine-building sector in terms of the probability of their occurrence, \%

\begin{tabular}{|l|c|c|}
\hline \multicolumn{1}{|c|}{ Group } & $\begin{array}{c}\text { Improved innova- } \\
\text { tive products }\end{array}$ & $\begin{array}{c}\text { New innovative } \\
\text { products }\end{array}$ \\
\hline $\begin{array}{l}\text { The risk of projects related to the } \\
\text { promotion of innovative products }\end{array}$ & $20-30$ & $25-35$ \\
\hline $\begin{array}{l}\text { The risk of projects at the intro- } \\
\text { duction stage }\end{array}$ & $30-40$ & $35-45$ \\
\hline $\begin{array}{l}\text { The risk of projects at the stage } \\
\text { of development work }\end{array}$ & $55-65$ & $65-75$ \\
\hline $\begin{array}{l}\text { The risk of projects at the re- } \\
\text { search stage }\end{array}$ & $65-70$ & $75-85$ \\
\hline $\begin{array}{l}\text { The risk of projects at the stage } \\
\text { of exploratory research }\end{array}$ & $75-85$ & $90-95$ \\
\hline
\end{tabular}

Data from expert studies confirm that projects related to the promotion of innovative products are of the greatest interest for implementation, while projects at the stage of exploratory research and research are the most risky, therefore potential investors are rarely interested in their implementation.

This is due to the fact that at the stage of exploratory and applied research risks of late receipt or even non-receipt of expected scientific results, budget overruns, which was allocated to these works, may occurred [17, 18].

\section{Methods of research}

Currently, the financing of innovative projects uses the planned cost estimates (fixed price method). The contractor achieves the result at the expense of the financing by the customer within the price, which is equal to the amount specified in the fixed estimate, in which all expenses are included according to the items. It seems that this method in conditions of innovative uncertainty is ineffective, because in the process of scientific research additional unpredictable costs may arise [19, 20].

The risks of the enterprise that makes long-term investments to finance the initial stages of research and development projects of an innovation project are significantly higher than those of external investors who invest in the final stages of development and production development (Fig. 1). 


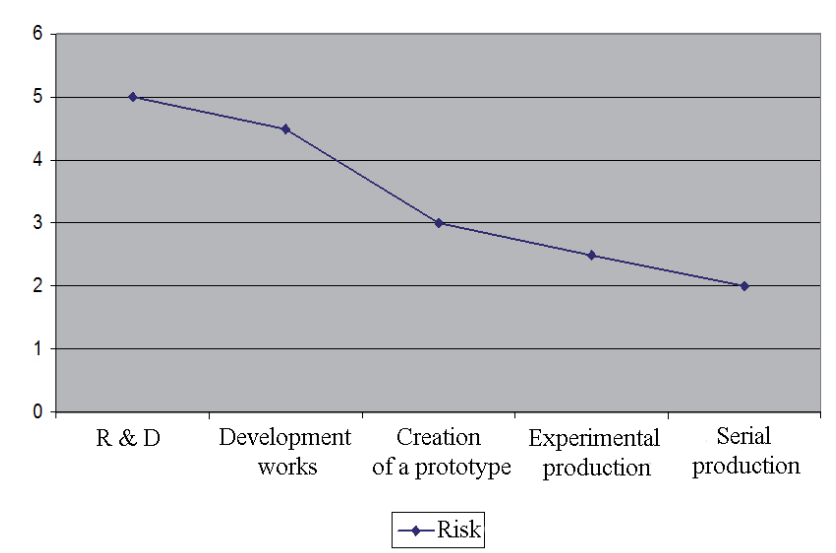

Fig. 1. Change in the level of risks at different stages of the innovation project

The method of reimbursement of expenses is applied in those cases when the performance of urgent and very complex research works is associated with high risk and often requires revision of the amount of financing. To successfully complete and obtain the planned result, it is advisable not to set a firmly fixed amount of funding, but to keep the budget open to increase, if necessary, its expenditure side. This will enable researchers to free up additional time for the successful completion of research work within the established timeframe [21].

\section{Research results}

As a result of the research it is found that an integrated system of protection against risks should ensureachievement of such criteria as patent purity, rate of return, license protection, novelty, priority of innovation directions, competitiveness of the introduced technologywhen implementing an innovative project.

The main ways to protect against innovation risks are the continuous monitoring of information in the field of innovation developments and advanced scientific and technical achievements, cooperation with the leading production, engineering, service and consulting centers.

The integrated approach assumes inclusion of all resources of the enterprisein system of protection against risks, and also potential of external cooperating state and non-governmental organizations. A special role in the complex system of protection against risks belongs to the risk management service of the enterprise. Planned, organizing, coordinating and information-support functions are assigned to it.

The complex system of protection against risks of machine-building enterprise is provided by internal and external subjects. Internal subjects of protection against risks include its owners, managers of all levels, as well as leading specialists and all personnel, as well as the risk management service of the enterprise.

This unit is entrusted with the functions of preparing, planning and carrying out measures to counteract hazards, threats and risks, protecting trade secrets and intellectual property, carrying out information and analytical work, countering competitive intelligence, providing methodological assistance to all structural divisions of the enterprise to implement measures aimed at reducing risks of innovation.
External subjects of the system of protection against risks of innovation activity include state authorities and administrations, subjects that invest innovative projects, partner enterprises, counterparties.

The effectiveness of risk reduction activities is largely due to the level of organization of interaction in this complex issue. The mechanism of interaction should include internal and external components, the legal basis for their joint work, information support system, management system, all types of planning activities to ensure risk reduction, coordination of common actions, logistics and financing.

The internal component of the mechanism of interaction in the system of risk protection includes the heads of the enterprise and its structural divisions, the head and specialists of the risk management service, orders, instructions for risk reduction, system for managing innovation activities of the enterprise and its structural units, system of external relations of the enterprise, system of financing and logistics.

The external component of the interaction mechanism in the risk reduction system of the enterprise includes mechanisms for managing innovation activities on the part of state authorities and management, banking institutions, investors, partner enterprises and other organizations.

In addition, the system of risk protection is aimed at timely detection of real and potential threats and risks for the operation of the enterprise, determining their sources and the likelihood of implementation.

The basis of the risk protection system is proposed to apply 13 principles that define the basic requirements for the construction of a protection system:

1. The principle of normativity means that the system of protection against the risks of the enterprise is created taking into account the norms of legislation, taking into account the methods and means of stimulating innovation activity envisaged by the legislation.

2. The principle of economic validity provides that the system of protection against risks is created taking into account the possible losses of the enterprise as a result of the implementation of threats and risks. The cost of creating a system of protection against risks should not affect the performance of the financial and economic activities of machine-building enterprise.

3. The principle of complexity implies that the system of protection against risks has a regular risk management service. All activities to counteract the threats and risks of the innovation activity of machine-building enterprise should be carried out on the basis of a developed strategy for protecting against risks, tactical and operational plans involving all financial, logistical, intellectual, information and other resources available in the organization.

4. The principle of rapid response provides for an immediate response from the risk protection system to emerging hazards, threats and risks. Priority is given to preventive actions that prevent undesirable events and events in the external and internal environment.

5. The principle of continuity means that the system of protection against risks of machine-building enterprise should be continuous.

6. The principle of effectiveness, in which the system of protection against risks always works in an active mode.

7. The principle of adequacy implies that the costs of construction, maintaining and ensuring the operation of the system of protection against risks are adequate to the level of real and potential hazards, threats and risks, as 
well as to the level of its financial, economic and other opportunities. Measures and remedies must be justified in terms of given level of material costs, threats and degree of danger.

8. The principle of resource endowment, in which the risk protection service must have at its disposal all the types of resources necessary for its activities to perform the assignedtasks.

9. The principle of development provides continuous improvement of means and measures to protect against the risks of the innovation activity of machine-building enterprise.

10. The principle of administrative management of the system of protection against risks provides for centralized management. The first head of the organization should directly manage the development of a risk protection policy and strategy, task the head of the risk management department to develop tactical and operational plans, make decisions regarding financing and comprehensive support of the risk protection system and be promptly informed about its current and future activities.

11. The principle of coordination provides that the functioning of the system of protection against risks of innovation activities of machine-building enterprise should be carried out on the basis of coordination of the activities of the risk management unit with other structural subdivisions of the organization and external organizations.

12. The principle of professionalism provides that specialists in the risk management system must have a high professional level, education and special training in various areas of protection against risks.

13. The principle of information disclosure provides that investors, heads of the organization and all structural divisions engaged in innovation activities, as well as personnel should be constantly informed by security specialists about threats, risks, methods of protection against risks of innovation activity of the enterprise, and receive recommendations on counteraction to them.

\section{SWOT analysis of research results}

Strengths. The proposed mechanism of an integrated system to protect against the risks of innovative activities of machine building enterprise allows to build an effective system to counteract threats to innovation that can counteract real and potential external and internal factors that are unfavorable for the enterprise, capable of ensuring its stable operation and sustainable development in conditions of high uncertainty of innovation processes.

Weaknesses. The weakness of the proposed mechanism of an integrated protection system is the failure to provide a realistic assessment of the analyzed indicators.

The most important indicator is the risk of unbalanced liquidity and solvency, which is based on the imbalance of assets and liabilities of the enterprise in terms of time.

Opportunities. In world practice, the liquidity ofthe enterprise is viewed as a stock or as a flow. In the first case, the ability of the enterprise to pay its current obligations at a certain point in time is implied. Liquidity as a flow is determined for a specific period or for a future. The liquidity of the enterprise is considered from the point of view of both categories.

Threats. It is advisable to assess the liquidity risk by calculating several key indicators that are absolute and relative. These include the net difference, the cumulative difference, the cumulative difference in the relative value, the ratio of the cumulative difference to the total amount of assets.

\section{Conclusions}

Thus, in modern conditions, it is possible to create favorable, safe conditions for the innovation activity of the enterprise only on the basis of an integrated approach. It is a comprehensive protection system that allows timely detection, assessment and effective counteraction to the dangers, threats and risks that may arise in different areas of the internal and external environment of the enterprise.

As a result of the studies it is proved that:

1. Innovative projects are the most risky for introducing risks and threats to a market economy. For most investment companies, financial institutions and banks, the availability of innovation in projects is a deterrent to financing.

2. The corporate resources of the enterprise, as well as the resources of various external organizations, with which the enterprises interact on the basis of mutual interest in counteracting dangers, threats and risks of innovation activity, are the basis of an integrated system of protection against risks of the innovative activity of machine-building enterprise.

3. Innovation risk for the enterprise is in the safety of commercial secrets and information resources, in protection from unauthorized access, reliable operation of communication equipment, computers and automated control systems.

4. The enterprise loses part of the profit not only because of the absence of a mechanism for protection against risk, but also because of the late repayment of the loan and interest on it. This is a consequence of the unbalanced amounts of expenses, as well as the consequence of inflexibility in determining the amount of risk relative to borrowed funds and credit.

5. The main ways to reduce risks at the stage of development work for «Dnepr Polymermash» enterprise could be a constant personnel potential building(first of all, upgrading the skills of project managers and innovative managers); bringing the material and technical base to modern world standards; use of automatic design systems; involvement of experts in patenting and certification of products.

6. The application of an integrated approach also provides an assessment of the main criteria that are considered fundamental in world practice, namely: reputation, opportunities, capital, conditions for the implementation of the innovation project. The main importance has the study of the qualities of management and professional level of the leaders of the innovative project as a competitive advantage of the enterprise.

\section{References}

1. Greve, H. R. Exploration and exploitation in product innovation [Text] / H. R. Greve // Industrial and Corporate Change. 2007. - Vol. 16, № 5. - P. 945-975. doi:10.1093/icc/dtm013

2. Cunha, M. P. E. Order and Disorder in Product Innovation Models [Text] / M. P. E. Cunha, J. F. S. Gomes // Creativity and Innovation Management. - 2003. - Vol. 12, № 3. - P. 174-187. doi:10.1111/1467-8691.00280 
3. Hirunyawipada, T. Consumer innovativeness and perceived risk: implications for high technology product adoption [Text] / T. Hirunyawipada, A. K. Paswan // Journal of Consumer Marketing. - 2006. - Vol. 23, № 4. - P. 182-198. doi:10.1108/ 07363760610674310

4. Choi, T. Y. The supply base and its complexity: Implications for transaction costs, risks, responsiveness, and innovation [Text] / T. Y. Choi, D. R. Krause // Journal of Operations Management. - 2006. - Vol. 24, № 5. - P. 637-652. doi:10.1016/ j.jom.2005.07.002

5. Im, S. Antecedents and Consequences of Creativity in Product Innovation Teams [Text] / S. Im, M. M. Montoya, J. P. Workman // Journal of Product Innovation Management. - 2012. Vol. 30, № 1. - P. 170-185. doi:10.1111/j.1540-5885.2012.00887.x

6. Browning, T. R. Modeling impacts of process architecture on cost and schedule risk in product development [Text] / T. R. Browning, S. D. Eppinger // IEEE Transactions on Engineering Management. - 2002. - Vol. 49, № 4. - P. 428-442. doi:10.1109/tem.2002.806709

7. Markides, C. Disruptive Innovation: In Need of Better Theory* [Text] / C. Markides // Journal of Product Innovation Management. - 2006. - Vol. 23, № 1. - P. 19-25. doi:10.1111/ j.1540-5885.2005.00177.x

8. Illiashenko, S. M. Stratehichne upravlinnia innovatsiinoiu diialnistiu pidpryiemstva na zasadakh marketynhu innovatsii [Text] / S. M. Illiashenko // Aktualni problemy ekonomiky. - 2010. № 12. - P. 111-119.

9. Vorobiev, S. N. Sistemnyi analiz i upravlenie riskami v organizatsii [Text] / S. N. Vorobiev, K. V. Baldin. - Moscow: MODEK, 2009. - 760 p.

10. Griniov, V. F. Innovatsionnyi menedzhment [Text] / V. F. Griniov. - Ed. 2. - Kyiv: MAUP, 2001. - 152 p.

11. Ermasova, N. B. Risk menedzhment organizatsii [Text] / N. B. Ermasova. - Moscow: Nauchnaia kniga, 2011. - 120 p.

12. Illiashenko, S. M. Ekonomichnyi ryzyk [Text] / S. M. Illiashenko. Ed. 2. - Kyiv: Tsentr navchalnoi literatury, 2004. - 220 p.

13. Churikanova, O. Cognitive approach application for the typological classification of regions by level of industrial development [Text] / O. Churikanova // Technology Audit and Production Reserves. - 2015. - № 1/7 (21). - P. 28-31. doi:10.15587/2312-8372.2015.38681

14. Antoniuk, O. P. Research of the interrelationship of basic macroeconomic indicators of Ukraine on the basis of simultaneouse quations [Text] / O. P. Antoniuk, A. S. Korkhin // Aktualni problemy ekonomiky. - 2015. - № 6 (168). - P. 410-416.

15. Sydora, T. Yu. Analiz prybutkovoi innovatsiinoi diialnosti promyslovoho pidpryiemstva v umovakh tsyklichnykh ekonomichnykh protsesiv [Text] / T. Yu. Sydora, O. H. Yakovenko // Aktualni problemy ekonomiky. - 2011. - № 7 (121). P. 329-338.

16. Bielkina, I. A. Diahnostyka bezpeky tsilisnosti informatsiinoho pidpryiemstva yak sotsialno-ekonomichnoi systemy [Text] / I. A. Bielkina, O. P. Antoniuk // Naukovyi visnyk Mizhnarodnoho humanitarnoho universytetu. - 2015. - № 11. - P. 310-312.

17. Polins'kyy, O. Development of risk management activities in innovation activity of engineering enterprise [Text] / O. Polins'kyy // ScienceRise. - 2014. -№ 4/1 (4). - P. 47-51. doi:10.15587/2313-8416.2014.28955
18. Polins'kyy, O. Risk management in the context of innovation projects implementation at machine-building enterprises [Текст] / O. Polins'kyy, A. Shyrin // Technology Audit and Production Reserves. - 2016. - № 1/3 (27). - P. 54-57. doi:10.15587/ 2312-8372.2016.59709

19. Krylov, E. I. Analiz effektivnosti investitsionnoi i innovatsionnoi deiatel'nosti predpriiatiia [Text] / E. I. Krylov, V. M. Vlasova, I. V. Zhuravkova. - Ed. 2. - Moscow: Finansy i statistika, 2003. - 608 p.

20. Stadnyk, V. V. Innovatsiinyi menedzhment [Text] / V. V. Stadnyk, M. A. Yokhna. - Kyiv: Akademvydav, 2006. - 464 p.

21. Chetyrkin, E. M. Finansovyi analiz proizvodstvennyh investitsii [Text] / E. M. Chetyrkin. - Moscow: Delo, 2008. - 256 p.

\section{ВНЕДРЕНИЕ КОМПЛЕКСНОЙ ЗАЩИТЫ ОТ РИСКОВ}

\section{В ИННОВАЦИЯХ МАШИНОСТРОИТЕЛЬНОГО ПРЕДПРИЯТИЯ}

Предложена комплексная система защиты от рисков инновационной деятельности машиностроительного предприятия, которая включает принципы: нормативности, экономической обоснованности, комплексности, быстрого реагирования, непрерывности, действенности, адекватности, обеспеченности ресурсами, развития, административного управления, координации, профессионализма, раскрытия информации. Предусматривается также оценка основных критериев, а именно: репутации, возможностей, капитала, условий реализации инновационного проекта.

Ключевые слова: риски инновационной деятельности, комплексная система защиты, риск-менеджмент, методы финансирования инновационных проектов.

Polins'kyy Olexandr, PhD, Associate Professor, Department of E-Economics and Economic Cybernetics, State Higher Educational Institution «National Mining University», Dnipro, Ukraine, e-mail: a_pol@mail.ru, ORCID: http://orcid.org/0000-0002-7193-7883

Bielkina Iryna, PhD, Associate Professor, Department of E-Economics and Economic Cybernetics, State Higher Educational Institution «National Mining University», Dnipro, Ukraine, e-mail: irinabelkina88@gmail.com, ORCID: http://orcid.org/0000-0002-0789-2545

Churikanova Olena, PhD, Associate Professor, Department of E-Economics and Economic Cybernetics, State Higher Educational Institution «National Mining University», Dnipro, Ukraine, e-mail: elen.c@mail.ru, ORCID: http://orcid.org/0000-0001-5703-2271

Shyrin Artem, PhD, Associate Professor, Department of Software and Computer Systems, State Higher Educational Institution «National Mining University»,Dnipro,Ukraine, e-mail: kym0k@bk.ru, ORCID: http://orcid.org/0000-0003-0026-2767

Yakovenko Tetiana, PhD, Associate Professor, Department of E-Economics and Economic Cybernetics, State Higher Educational Institution «National Mining University», Dnipro, Ukraine, e-mail: taniav@i.ua, ORCID: http://orcid.org/0000-0003-1900-8283

Antoniuk Oksana, PhD, Associate Professor, Department of E-Economics and Economic Cybernetics, State Higher Educational Institution «National Mining University», Dnipro, Ukraine, e-mail: antonyukok@gmail.com,ORCID:http://orcid.org/0000-0001-8619-2530 